\title{
THE RECONSTRUCTION OF ANCIENT CHINESE
}

BY

\section{BERNHARD KARLGREN.}

The linguistic study of Chinese, for a long time much neglected, has of late become the object of considerable interest. After the rather amateurish attempts in phonetic history made by EDkiss, Volpicelli and Kühnert, something more serious and scientific was for the first time produced by Schank in a small article Ancient Chinese phonetics ( $T^{\prime}$ oung $P_{a 0}, 1900$ ). A great step forwards in this branch was taken when PeLtiot (in various articles in Journ. As. and T. Pao, 1911-14) and Maspero (Études sur la phonétique historique de la langue Annamite, BEFEO, 1912) adranced provisional systems for the reconstruction of Ancient Chinese. These attempts were followed up by myself in a compreheusive work Etudes sur la Phonologie Chinoise (3 vol. 1915, 16, 19), based on a comparative study of modern dialects and ancient sources, where I established a detailed system of reconstructing the language embedded in the dictionary Ts'ie yün (written in the 6th c. A.D.) ${ }^{1}$ ).

Henri Maspero has recently published a large and highly interesting treatise on the same subject: Le dialecte de T'liangngan sous les T"ang, BEFEO 1920. As the best and most reliable results in cases like this are always gained by discussion

1) Cf. also Karlgren: Prononciation ancienue de caractères Chinois figurant daiss les transcriptions Bouldhiques, T. Pao 1919. 
between the authors initiated in the particulier branch of study, I shall allow myself to try to throw new light upon some of the ideas brought forward by Maspero in his work.

The work in fact comprises two main theses: an account of the language of Ts'ie yün and a description of the evolution of the language in the course of the T'ang epoch. The latter part of his work - full as it is of sagacious observations and interesting ideas it is not my intention to touch upon here. I am merely going to discuss his proposals concerning the reconstruction of Ancient Chinese.

I naturally do not want here to dwell upon those many and essential points where Maspero has accepted - and sometimes confirmed with new and valuable material - my results in the Phonologie. Such points, which I pass without discussion and which now may be considered as definitely established, are:

1) The non-yodicised nature of the initials in words which occur in the IId division of the rime tables, 加, 巴, 咸, 班 ete; Maspero, following Scbaank, had earlier $(1912)^{1}$ ) supposed mouillation in these words.

2) The dividing of the initials 照, 穿, 狀, 審, 福 in one supradental series $\left(t s, t s^{\circ}, d \tilde{s}^{*}, s\right)$ aud one palatal $\left(t^{\prime} \dot{s}, t^{\prime} \xi^{*}, d z^{\prime}, \dot{s}, z^{\prime}\right)$,

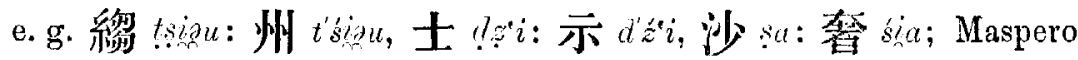
1912 had exclusively palatals.

3) The formation, in early T'ang, of a dentilabial nasal $\%$, e. g. 無 $m \underset{j}{i} u>\stackrel{v}{m u}$; Maspero $1912 m j i \underset{u}{ }>w u$.

1) MasPero: Etudes sur la phonétique historique de la langue Annamite. It must be remembered that the reconstruction of the old pronunciation there proposed - based on the rime tables - was considered by Maspero to represent the language of Ts ie yün. $\mathrm{He}$ writes (p. 120): Une analyse approfondie des pronouciations du Ts'ie yun (surtout d'après le Kouang sun) a été fuite par des auteurs du temps des Song et des Yaan, et ils ont condensé les résultats de leur recherches en tableaux assez cluirs et de consultation aisće. Ils ne cherchaient pas, comme on l'a dit, a noter les prononciations de leur temps, mais a elasger celles des anciens dictionnaircs. 
4) The evolution $m>m b, n>n d$ etc. in early 'T'ang, as explaining a. o. the Kan-on, e.g. 毛 mâu>mbâu, Kan-on ba-u.

5) The original final ie $(<i a)$ in words of rime $\frac{1}{\not}$, e.g. 義 ngjie, in contrast to $-i$ in rimes 脂, 之; Maspero $1912 \mathrm{bad}-i \breve{e}$ in all these rimes.

6) Vocalic medial $u$ in the Ist division of certain groups (e.g. 官 kuan, Cantonese $k \bar{u} n$ ) against consonantic medial ${ }^{w}$ in the IId div. (e.g. 關 k kan, Cant. kwan).

7) -ong in rime 鍾, e.g. 菒 $k_{j} i^{2 \prime}$ ong against -ung in rime 東 IIId div., e.g. 弓 kjjung ${ }^{1}$ ); Maspero 1912 had -ung in the whole of the IIId division.

8) -o in rime 魚, e.g. 居 $k j i_{n}^{i n} 0$ against $-u$ in rime 虞, e.g. 俱 kjin ; Maspero 1912 had $-u$ in both.

9) The open -o (i) in rime 江, e.g. 江 king; Maspero 1912 -ang.

10) - a in the rimes 侯, 尤, 幽, e.g. 銁 kigu, 九 kijigu; Maspero 1912 had -"u.

11) The contrast between $\hat{a}$ "grave" in 哥 $k \hat{a}$, 安 ‘ $\hat{a}$ etc. (Ist division) and $a$ “aigu" in 加 $k a$, 咸 $k a m$ etc. (IId division); Naspero 1912 had the same $a$ in them all.

12) - $i_{a} a$ in rime 麻, IIId division, e.g. 者 $t^{\prime} s z_{n} a$; Maspero 1912 supposed -ie already for the T'ang epoch.

13) - an in rimes 欣, 文, e.g. 斤 kjian, 君kijuan; Maspero 1912 had - ĕn.

14) $-\partial m$ in rime 侵, e.g. 今 $k j i z m$; Maspero 1912 had - ĕm.

15) -ong in rime 蒸, e. g. 䫧 kijhang; Maspero 1912 had -ëng.

16) Medial " in rime 凡; Maspero 1912 believed medial $u$ with final labial consonant to be an impossibility in Chinese.

1) On p. 76 of his new work Maspero charges me with the supposition of a - "ong in rime秉: 局 $k j i^{2 x}$ ong. This is not true, see Phon. Chin. pp. 687 and 698 , where just

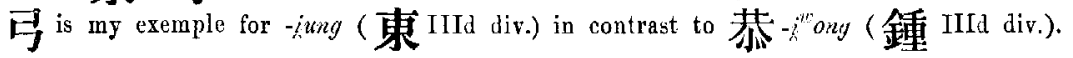


From these facts I pass over to more discussable things.

A. The $W u$ dialect and Sino-Korean.

Besides the old riming dictionaries aud the fan-tsie spellings, our most important old sources for the knowledge of the evolution of Chinese are the four "foreign dialects": Sino-Korean (abbr. Kor.) (about 600 A.D.), the Sino-Japanese Go-on (5th-6th c.), the Sino-Japauese Kan-on ( 7 th c.) and Sino-Annamese (end of the T'ang) ${ }^{1}$ ).

It therefore must be said to be a very radical step, when Maspero states that Sino-Korean just as well as Go-on are based on the old $\mathrm{Wu}$ dialect and consequently cannot be considered when it comes to the reconstruction of the Ts'ie yün dialect, which latter Maspero with good reasons considers as a Northern dialect.

This thesis of Maspero coutains two errors, and as we shall see ther have an unfavourable influence upon his reconstructive system.

1) Maspcro dates the Kan-on at the beginning of the 8th century, but this is surely too late. The traditions speak in favour of the 7 th, and this agrees well with the very strong position already obtained by Chinese learning in the beginning of the 8th centnry (Nihongi, etc). The predominance of Northern Chinese civilisation in Japan dates from the Taikua era in the middle of the 7th e. Thus if we for the Kan-on say the later part of the 7 th $c$. , we are on the safe side.

In Koren there were several waves of forcigu influence. There are historical records

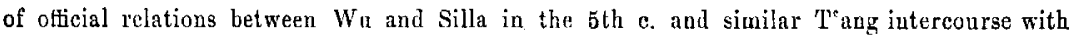
Korye. But one must not exaggerate the value of such dalcs as mile stones for linguistic research. The way from North China to Korea was so short that certainly private scholars found thcir way there independertly of oflicial irtercourse. Whichever of the loan waves imported the Chinese pronunciation surviving in the Sino-Korcan, at any rate it was not appreciably later than 600 A.D., for the language upon which it was based -- though Northern Chinese as will be proved above - had not yet gone thruugh the evolutions $m>m b, n>n d$ of the sweeping nasalisations which characterizcd the fth century, as testified by the kan-on.

On the other hand I would hesitate to date it earlier than the 6 th $\mathrm{c}$. The treatment of final - $t$ : 害制 Auc. kat, Kor. kal etc, explainable only by the Northern Chinese evolution $-t>\delta(>r$ ?), which cannot have commenced very much earlier than T"ang, shows that we cannot go much higher than $600 \mathrm{~A}$. D. Thus the Sino-Korean was practically contemporaneous with the 'T's'ie $y$ iin. 
1) Even if both Kor. and Go-ou were based on the $\mathrm{Wu}$ dialect, one has no right to disregard them entirely, as Maspero has done, when it is a question of reconstructing the ancient North Chinese. The $\mathrm{Wu}$ dialect was no Indo-European or Bantu language but a sister dialect of that of Ts'ie yüu (and very similar to it in many respects, as is shown by the Go-on). And if two dialects differ on certain points, they can agree on other points, thanks to a parallel evolution $^{1}$ ). In opposition to Maspero I therefore lay down this principle: whenever the $W u$ dialect (as revealed in (Go-on) shows up the same distinctions of word groups as the Ts'ie yün, it must be taken into consideration when it comes to interpreting the meaning of these distinctions.

A striking example of the importance of this principle is the word group placed under rime 江 in Ts'ie yün. Go-on $(\mathrm{Wu})$ is the only one of all the dialects which treats its rocalism differently both from rime 唐 and rime 陽, and thus it is just the $\mathrm{Wu}$ dialect that gives us the key to the old head rowel in Northem Chinese: 江 kiing.

2) And still more important: Siro-Korean was not based on the $W u$ dialect. In fact it is strange that Maspero dares to be so positive on this point that he neglects throughout his work the Sino-Korean, one of our oldest and most valuable records of the ancient prounciation. For his reasons are decidedly weak. On p. 9 he gives an account of the introduction of Chinese into Korea, and the account is full of expressions like "il est vraiscmblable, il est probable". The result of his inquiry is to give the reader the strongest impression that the historical facts teach us absolutely nothing as to the North of South Chinese nature (Ts'ie yün or Wu)

1) So e.g. the modern dialects, so strongly diverging in many respects, have as a common traits that anc. $-\hat{a}$ in open syllable has become $-0: \frac{\overline{D J}}{\mathbf{D J}} k \not a>k$. 
of the Kor. loan words. One is therefore quite astonished, when Maspero from his entirely negative exposé draws the following conclusion:

"J'admets de façon générale que la prononciation actuelle est au fond celle de Silla, basée sur le dialecte de $W u$ du $V^{e}$ siècle environ; mais qu'elle a subi l'influence de celle de Korye, basée sur un dialecte septentrioual du temps des T'ang".

For my part I state exactly the contrary: Sino-Korean is essentially based on the old Northern Chinese of the Suei and early $T^{*} a n g$ (and therefore one of our most precious documents for the interpretation of the $\mathrm{Ts}^{*}$ ie yün), with certain and very few traits which might suggest a $\mathrm{Wu}$ influence. This statement $\mathrm{I}$ am ready to prove by the following surrey of the conformity between SinoKorean on the one hand and the Kan-on (based on the North Chinese of the 7 th c.) and the already established facts concerning the Ts'ie yiun on the other.

a) The sonant initial occlusives and fricatives:

$\begin{array}{llll}\text { Ts'ie yün } & \text { Kor. }^{1} \text { ) } & \text { Kan-on }{ }^{1} \text { ) } & \text { Go-on } \\ \text { 琶 } b^{\circ} \ddot{j} i & p i & p i & b i \\ \text { 棋 } g^{\circ} j i & k i & k i & g i \text { etc. }\end{array}$

Kor. agrees with Kan-on, not with Go-on.

b) The IVth division of group 蟹 (rime 弯):

\begin{tabular}{|c|c|c|c|}
\hline 雞 Kiei & kiei & $k e i$ & $k a i$ \\
\hline 低 tiei & $t i e i$ & tei & ta $i$ \\
\hline 軆 liei & $l i e i$ & $r e i$ & $a i$ \\
\hline 㯙 piei & $p^{* i e i}$ & pei & $i i$ \\
\hline
\end{tabular}

Kor. agrees with the North Chinese, not with Go-on.

c) The Ist division, ho k'ou, of group 偮 (rime 兏):

1) I always give here the Sino-Korean and Sino-Japanese forms as they are spelled in the old spelling systems, not as they are pronounced to-day. 


$\begin{array}{llll}\text { Ts'ie yün } & \text { Kor. } & \text { Kan-on } & \text { Go-on } \\ \text { 瑰 kuai } & k o i & k u-2 v a-i & k e \\ \text { 雷 } l u a i & l o i & r a i & r e \\ \text { 腿 } t^{*} u a i & t^{*} \circ i & t a i & \text { te }\end{array}$

Kor. agrees with North Chinese, not with Go-on. (This case should not be confused with the phenomenon discussed under $o$ below.)
d) The Ist division of group 咸 (rimes

$\begin{array}{llll}\text { 甘 } k a m & k a m & k a n & k o n \\ \text { 頜 } t^{*} a m & t^{*} a m & t a n & \text { ton }\end{array}$

Kor. agrees with Kan-on, not with Go-on.

e) The ho k'ou of rime 仙, and $k^{*}$ ai and ho k'ou of rime 元:

[Let us first remark that in k'ai k'ou the regular correspondence to Anc. Chin. - än (rime 仙) is Kor. -an (pronounced - $\ddot{\text { an }}$ in older times), Kan-on and Go-on -en, e.g.

\begin{tabular}{|c|c|c|c|}
\hline 虔 g'jiän & $k a n$ & ken & gen \\
\hline 禪 śzïn & $\operatorname{sian}$ & $\operatorname{sen}$ & $\varepsilon e n]$ \\
\hline \multicolumn{4}{|c|}{ ๙) Rime 仙, ho k'ou: } \\
\hline$-i^{l n} a \ddot{a} n$ & $-u \partial n,-\partial n$ & $\begin{array}{l}\text {-en } \text { gutt. } \\
\text { other in. }\end{array}$ & $\begin{array}{l}-o n \text { or }- \text { tan } \\
-e n\end{array}$ \\
\hline$g^{*} j i^{w} \ddot{u} n$ & $k u a n$ & ken & gon \\
\hline$g^{*} j_{l}^{l t} \ddot{a} n$ & kuan & ken & $g u-w a n$ \\
\hline 全 $d z^{n} \ell_{n}^{* n} a n$ & $\check{c} \cdot \partial n$ & $\operatorname{sen}$ & $z e n$ \\
\hline
\end{tabular}

Kor, head vowel follows North Chinese, not Go-on.

今) Rime $\vec{\pi}, k^{\prime} a i$ k'ou:

$\begin{array}{llll}\text { 言 ? }{ }^{1)} & \text { an } & \text { gen } & \text { gon } \\ \text { 掀 } & \text { han } & \text { ken } & \text { kon } \\ \text { 建 } & k a n & k e n & k \text { kon } \\ \text { 憲 } & k a n & k e n & k o n\end{array}$

1) Will be discussed later. 
Kor. and Kan-on treat it exactly like r. 仙 (Auc. - än), Go-on differently.

r) Rime 元, ho k'ou:

Ts'ie yün

Kor.

Kan-on

Go-on

\begin{tabular}{|c|c|c|}
\hline gutt. & uan & en \\
\hline & $-2 n$ or $-a n$ lab. & $-e n$ or $-a n$ \\
\hline & uan & gen \\
\hline & huan & $k e n$ \\
\hline & kuon & ken \\
\hline & $u ə n$ & $e n$ \\
\hline & pan & $p e n, p a n$ \\
\hline & pan & pen \\
\hline & $p^{e} \iota n$ & pan \\
\hline
\end{tabular}

\begin{tabular}{c|l} 
& Go-on \\
gutt. & $-u a n$ or $-o n$ \\
lab. & $-a n$ or - on \\
& gu-wan \\
kon \\
kn-wan \\
on \\
bon \\
ban \\
pon
\end{tabular}

After gutturals Kor. and Kan-on have always the rocalism of r. 仙 (Kor. -an, Kan-on -en), while Go-on breaks away altogether. After labials both Kor. and Kan-on fluctnate between - an and the vocalism of 仙 $\left.(-2 n,-e n)^{1}\right)$. Go-on is quite different.

1) One of the most eurious passages in Maspero's new book is 1 . 59-60, where he asserts that $-e n$ in the pen (ken) ete. of the Kan-on is a late "correction", in spite of the faet that it agrecs so extremely well with the pan of Kor. It would be strange indeed if the Japanese just in this respect should have been seized by such a fervour of "correetion". Out of the 3,100 common characters in my Phonol., 16 belong to rime $\overrightarrow{\vec{\jmath}}$ (and corresponding rimes in other tones) with labial initials; 13 of these have pen (hen) etc.: Maspero, however, has even imagined a reason for the correction. In words like 蕾, 反 spelled 袁, 遠 (eir) one corrected pan into pen. But in words like 萬 spelled 販 (an alleged pan) the a was preserved: ban. This sounds very inventive and holds good in the 5 examples given by Maspero. But it does not do e.g. for 榞 lian-on petu (hetsu), spelled 灰: 伐, nor for 氿 Kan-on pen (hen), spelled 穻: 梵

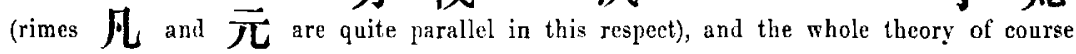
falls to the ground. Nothing would be easier than to vindicate onc's theories, if one could explain scores of examples that go against them as later interpolations. The pen (hen) words of Kan-on, pointing in the same direction as the pan, pam of Kor, are rery valuable and interesting. 
f) Rime 文:

Ts'ie yün

Kor.

Kan-on

Go-on

君 kijuan

kun

kun

kon

紛 pjinan

pun

pun

pon

問 mizuan

mun

bun

mon

Kor. agrees with Kan-on, not with Go-on. (That Kor. and Go-on both have $m$ - but Kan-on $b$ - is due to the fact that North Chinese $m$ - became $m b$ - first in the 7 th c.).

g) Rimes 清 and 靑, and IIId div. of rime 庚.

輕 kjï̈ng

聲 siciong

經 kieng

京? kiang (i. e. kiüng) kei

siang

kiang

kiang $s e i$

$k e i$

$k e i$ $k i-y a-u$

$s i-y a-u$

$k i-y a-u$

$k i-y a-u$

Kor. and Kan-on have the same head rowel $(\partial, e)$ as in rime 仙 (A. Chin. - $\ddot{\text { an }}$ ), Go-on has - a-.

h) Rime 陽:

糧 ljikang liang

相 siang siang

$\begin{array}{ll}r i-y a-u & r a-u \\ s i-y a-u & s a-u\end{array}$

Kor. and Kan-on render the medial $i$, Go-on not.

i) Rime 江:

江 king

lang

$k a-u$

$k o-\imath$

雙 sing

sang

$s a-u$

$s o-u$

Kor. agrees with Kan-on, not with Go-on.

j) Rime 主:

流 ljiou liu

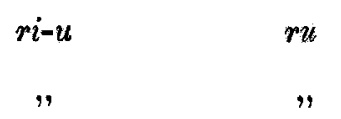

王留 "

Kor. and Kau-ou render the medial $i$, Go-on not.

k) Rime 模:

沽 kno

loo

ko

$k u$

盧luo

lo

ro

$r u$ 


$\begin{array}{llll}\text { Ts'ie yün } & \text { Kor. } & \text { Kan-on } & \text { Go-on } \\ \text { 都 tuo } & \text { to } & \text { to } & \text { tu }\end{array}$

Kor. ayrees with Kan-ou, not with Go-on.

l) Rime 虞:

$\begin{array}{llll}\text { 拘 } k j i u v & k u & k u & k o \\ \text { 愚 } n g j i u & u & g u & g o \\ \text { 榆 } i u & i u & i u & i o \\ \text { 夫 } p j i u & p u & p u & p o\end{array}$

Kor. agrees with North Chinese, not with Go-on.

m) Rime 東, Ist division:

\begin{tabular}{|c|c|c|}
\hline I kung & kong & $k o-\iota$ \\
\hline 東 tung & tong & $t o-u$ \\
\hline
\end{tabular}

Kor. agrees with Kan-on, not with Go-on.

n) Rime 鍾:

\begin{tabular}{|c|c|c|c|}
\hline 萙 $k j i^{i^{*}}$ ong & kong & $k i-y o-u$ & $k u$ \\
\hline 鍾 $t^{\prime} s^{\prime} t^{\prime \prime} 0 n g$ & čiong & $s i-y 0-u$ & $s i-y u$ \\
\hline 鋒 $p j i^{\prime \prime \prime}$ ong & pong & $p o-n$ & $p^{n}$ \\
\hline
\end{tabular}

Kor, agrees with North Chinese, not with Go-on.

o) Finally we have a case which is of extreme importance as it affects a large percentage of the whole word material: the socalled independent IId division.

$\begin{array}{llll}\text { 加 } k a & k a & k a & k e \\ \text { 馬 } m a & m a & b a & m e \\ \text { 瓜 } k^{*} a & k u a & k u-w a & k e \\ \text { 皆 } k a i & k a i & k a i & k e \\ \text { 敗 } b^{\prime \prime} a i & p^{\circ} \bar{a} i & p a i & b e \\ \text { 減 } k a m & k a m & k a n & k e n \\ \text { 問 } k a n & k a n & k a n & k e n \\ \text { 棧 } d g^{*} a n & c a n & \text { san } & \text { sen }\end{array}$

Kor. agrees with North Chinese, not with Go-on. 
Maspero has not failed to notice the striking contrast between Sino-Korean and Go-on (Wu) in this last respect, and he tries to get out of the difficulty by assuming that the evolution $k a>k i a>k e$ ete. in the $W u$ dialect took place after the Sino-Korean was calked upon the said dialect but before it was made the base of Go-on. Even with the dating of Maspero (Sino-Kor. 5th c., Go-on end of the 6 th) it is very unlikely that such a radical change had time to be carried through. And it must be added, first that Sino-Kor., for reasons given above p. 4, caunot be dated as early as the 5th c., and secondly that Maspero without convincing reasons dates Go-on later than does the common tradition. There are no safe points of appui, and we can only date the Go-on approximately (5th or 6th c.). After the long series of resemblances between Sino-Korean and North Chinese (T'sie yün and Kan-on) shown abore, we cannot hesitate a moment in stating that in this respect as in others Sino-Korean, in coutrast to Go-ou ( $\mathrm{Wu})$, is based upon Northern Chinese.

The only real support for his thesis that Sino-Korean is based on the $W u$ dialect which Maspero has been able to offer is the similar way of treatiug certain cases of medial $i$ in Kor. and Go-on:

\begin{tabular}{|c|c|c|}
\hline Ts'ie yün & Kor. & Go-on \\
\hline 金 $k j i m$ & kïm & kion \\
\hline 共 $k j i^{\prime \prime \prime}$ ong & kong & $k u$ \\
\hline $\begin{array}{r}\text { 薑 } k j \text { ijang } \\
\text { but }\end{array}$ & kang & $k a-u$ \\
\hline 心 siam & $\operatorname{sim}$ & $\sin$ \\
\hline 林 ljizm & $\lim$ & rin etc. \\
\hline
\end{tabular}

Maspero draws the conclusion that the $\mathrm{Wu}$ dialect possessed no yodicised gutturals but instead of this "le dialecte de Wou semble avoir possédé seulement une série vélaire articulée très en arrière sur le voile du palais analogue au ḳ faucal de l'arabe, probablement 
héritage de l'ancien langage local"' (!, p. 13). This would explain firstly why the medial $i$ was lost in the cases cited above, and secondly why Kor. had an $i$ before $i$ when this is the head vowel, in cases like:

$\begin{array}{lll}\text { Ts'ie yün } & \text { Kor. } & \text { Go-on } \\ \text { 記 } k j i & k \ddot{i} i & k i\end{array}$

For between " $k$ " and $i$ there would have arisen in Wu a parasitic a $: k i>\operatorname{lo} i$.

This theory seems rather seductive at first sight. But a closer examination shows it to be without foundation.

The theory purports, as we see, that both the contrast 金 K. kim, G. kon: 心 K. $\sin$, G. $\sin$ and the $\ddot{z}$ of Kor. kïi are due to a strongly velar articulation of the gutturals in $\mathrm{Wu}$; and the whole proof material is just these two phenomena.

Therefore it falls to the ground in the same moment it is shown that the same phenomena appear equally well after other initials, or even with no initials at all!

๔) To take the latter and most crushing evidence first, we have:

\begin{tabular}{|c|c|c|}
\hline Ts'ie yün & Kor. & Go-on \\
\hline 醫 $\ddot{j} i$ & $\ddot{i} i$ & $i$ \\
\hline 音 $j i z m$ & $\ddot{z} m$ & on \\
\hline 央 jizang & ang & $a-u$ \\
\hline 優 $j i g u$ & $u$ & $u$ \\
\hline
\end{tabular}

And if it is objected that here the laryngal explosive ' (like Germ. 'Ecke) plays the same "hardening" part as the "very velar" gutturals, then we have cases like

$$
\text { 友 } j i g u \quad u \quad u
$$

where there is an absolutely smooth ingress with neither any "very velar" guttural nor any laryngal explosive to influence the articulation - and yet the same hard $u$ !

f) In the second place it has to be remembered that the contrast 
kon: $\sin$ in Go-on is by no means consistently carried through. There are a number of -on (with lost medial $i$ ) also after other ivitials of various kinds. A good example is 品 Anc. pijim, Go-on pon, a very current reading, and we may further cite 嬸 A. śż

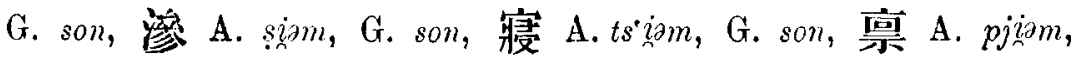
G. $p$ on ${ }^{1}$ ).

And still more important: we have perfectly regularly

$$
\begin{aligned}
& \text { Anc. ljiang Go-on ra-u, } \\
& \text { "siang } " s a-u \text {, } \\
& \text { "ljizu ", ru, (cf. p. } 9 \text { above), }
\end{aligned}
$$

thus two large groups where the medial $i$ is not rendered after $l$ and s. As the loss of medial $i$ in Go-on in the cases cited evidently cannot be due to an "articulation très en arrière, sur le voile du palais" of the $p, l$, and $s$, it follows that the whole of this phenomenon, Go-on's skipping the medial $i$ in cases like 金 kon, 品 pon, 糧 $r a-u$, 相 $s a-u$ has nothing whatever to do with the articulation of the gutturals in $\mathrm{Wu}$. The very audacious supposition of a set of faucal li. etc. in $\mathrm{Wa}$, built upon this phenomenon in Kor. and Go-on, must be emphatically rejected; we know so far nothing whatever of the guttural articnlation in $\mathrm{Wu}$ (nor in the "ancien langage local"!).

So far the criticism. But how is the peculiar attitude of Kor. and Go-on in the cases kïm-kon and kii to be explained? Nothing is more simple.

We must remember that both Kor. and Go-on are versions of the Aucient Chinese as resdered by foreigners. Now, there are numerous and anmistakable examples showing that certain sound combinations which seemed difficult to pronounce were simplified. Cf. for instauce Anc. d'z'in' $z^{\prime \prime} \ddot{n}$, Kan-on sen, Go-on zen! And it

1) It would never do, of coursc, to try to explain away these pon, son as later "corrections", see p. 8 above. 
often occurs that a phonem is properly rendered after certain initials, while it is skipped after others:

$\begin{array}{ll}\text { Anc. Chin. kuân } & \text { tuîn } \\ \text { Jap. kuan } & \text { tan }\end{array}$

If Sino-Japanese itself can skip the medial $u$ after certain groups of initials (dentals), there is nothing astonishing in the fact that it leaves out medial $i$ after certain initials:

Go-on $\quad k j(i) a m>k o n$ but $s i j m>\sin$

Similarly Kor. kj(i)am $>$ kïm but siam $>\operatorname{sim}$

( $\partial$ is regularly rendered by $o$ in Sino-Japanese, by $i$ in Kor.).

And the accordance between Kor. and Go-on $(\mathrm{Wu})$ is by no meaus so striking as Maspero believes. There are remarkable divergences.

Consonantic $?$ has been left out in both dialects after gutturals $^{1}$ ), e.g.

金 Anc. kjimm, Kor. kim, Go-on kon.

But in Go-on besides this it has been skipped also after certain other consonants, either sporadically, in certain rimes, e.g. 品 pon, or regularly, in other rimes, e.g. 糧 $r a-u$, 相 $s a-u$. To this there is no parallel in Kor.

Vocalic $i$ is always rendered in Kor., e.g. 堅 Anc. kien, Kor. kian. But when the guttural or laryngal initial is yodicised (which happens with rocalic $i$ ouly when this $i$ is the head rowel: rimes $-i,-i e,-e i)$, e.g. 記 kji there must have been some pronunciation difficulty. One was unable to pronounce $k j i, ; j i, ; j i$ etc. and rendered it by kii, hii, $\ddot{i}$. To this there is no analogy at all in Go-on!

Thus we see that the one support adranced by Maspero for his theory that Sino-Korean was based on the $\mathrm{Wu}$ dialect does not hold good. And against it we set the rich evidence furnished above $(a-o)$ : Sino-Korean was based on the North Chinese, and it has been unfavourable to the work of Maspero that he has neglected the valuable light it throws upon the Aucient Chinese of Ts'ie gün.

1) There are certain exccptions to this rule, a. o. the rimes 清, 联. 


\section{B. The rimes 同用 tiung yung and 獨用 tu yung.}

Everybody who studies more closely the problems connected with the reconstraction of the lauguage of Tstie yün gete a strong impression of the difficulty of interpreting the ancient difference between phonological groups which have become one already at an early date (e.g. rimes 咸 and 銜, 仙 and 先 etc.). And this has seduced Maspero into supposing that certain old rimes in Ts'ie yün were in reality identical - he supports this thesis by quoting a certain grouping of the rimes in the Kuang yün. This is in my opinion the second fundamental error in his treatise, and I think it has been disadvantageous to his results.

1) Let us first remark that the coupling of certain rimes as 同用 $t^{2} u n g$ yung and the placing of others as 獡用 $t u$ yung is not documented before the Kuang yün, consequently as late as 1007 A.D. It is only a tradition that attributes this arrangement to Hü King-tsung (living about 590-670 A.D., see Maspero p. 511), and as the work of this author is lost, there is nothing to prove that the grouping in Kuang yiin is identical with that in the book of Hï King-tsung ${ }^{1}$ ). One would therefore already a priori be justified in declaring that the said arrangement is too badly documented to allow any serious theories to be built upon it.

But for the sake of argument, let us suppose that Hü had brought together the rimes of Ts'ie yün in groups "t'ung yung" identical with those in Kuang yüu. It is none the less quite impossible to admit that these rimes were identical in the Ts'ie yün.

2) Why, in the first place, should the author have broken up a certain rime and distributed its words in two or more groups under different headings as if they had different riming parts (head vowel aud final cons.)? The only answer Maspero has to give is this (p. 70): "Je serais porté ì croire que la division de

1) The argument given by Maspero p. 53 for sueb an identity is quite insufficient. 
certaines finales en plusieurs rimes tong yong est purement arbitraire, et que là où elle ne sépare pas des mots ho-keou ou des mots à $i$ médial, elle est simplement due au désir de simplifier les recherches en répartissant sous plusieurs rubriques les mots trop nombreux".

It is easy to see what has been before Maspero's mind: the perfectly arbitrary dividing, in the old dictionaries, of the $p^{\prime}$ ing sheng rimes into one shang $p^{i n g}$ and one hia $p^{i} i n g$ section (which has nothing to do with "high" and "low" tones), in order to get sections of the same length as the shang, $k \ddot{u}$ and $j u$ sheny sections. But the difference is very great. There you know exactly which rimes belong to the first or the second section and thus have not to search in vaiu. If now out of two tiung yung rimes the one had contained words with guttural initials aud another those with other initials, then this could be said to "simplifier les recherches". But the words occur indiscriminately in the t'ung yung rimes, irrespective of the initials, and there is no way of knowing under which rime you have to look. If the rimes had been really identical, the arrangement would not have simplified but enormously conplicated the consultation of the dictionary.

But above all: it can never be a question of "simplifier les recherches en répartissant sous plusieurs roubriques les mots trop nombreux", so much follows from some simple statistics. Rime 東 comprises in the Kuang yün 348 characters (some with medial $i$, others without; if medial $i$ had played any part in the arrangement of the rimes, it stands to reason that this rime would have been

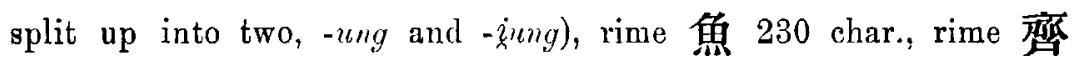
332 etc. But we find two t'ung yung rimes 岸 and 凡 of which the former has 11 characters and the latter 9! And if this distinction is due to the ho k'ou (") of the latter, as Maspero seems to think (which is impossible, as e.g. 山 comprises both -an and -"an), 
then there is no such difference between 咸 and 洤 (both IId division, $k^{\prime} a k^{\circ} \circ u$ ), which are t'ung yung and of which the former has 71 claracters and the latter $29^{1}$ ). If the rimes 咸 aid 检 were identical, what would be the sense in splitting up their 100 characters as being too numerous into two "rimes" in order to "simplifier les recherches", while one did not split up the 348 char. of 東 or the 332 of 荷?

Moreover, there are two t'ung yung rimes: 无 with 426 char. and 侎 with $35^{2}$ ). What would be the good of picking out of 461 characters only 35 and placing them apart under the heading 㗀, not dividing equally, if the idea was to divide a group that was too large into two snialler ones? The whole theory seems to me to be meaningless.

3) If Maspero thus can advance no plausible reason whatever for the t'ung yung arrangement, if it meant identity between the rimes, his theory becomes still more dubious when it turns out that he caunot carry it through and yet be consistent. Of this we can give several examples.

The rime 元 is t'ung yung with 魂 and 痕. Maspero constructs a $-2 n(-i a n)$ in 元 and a $-\partial n$ in 魂 and 痕. The difference between them thus is the quantity. Now there is, in Maspero's system, an exact parallel: for the rimes 仙 and 先 Maspero supposes -en (-ien) and for the rimes 頁, 暲, 鉌 $-\ddot{n} n(-i \ddot{e n})$; they also would be distinguished only by the quantity. Just as well as 元 is t'ung yneng with 謉, 痕 and is placed together with them in the rime list of Ts'ie yuin, the rimes 仙, 先 ought, according to Maspero's principles, to be tung yung with 鱼, 棓, 鉌 and stand close to them in the rime

1) The number of char. in Ts"ie yün of course is smaller, but the projortions are exactly the same as in Kuang yün.

2) Maspero p. 85 gives as belonging to rime 约 several char. which really belong to rime 尤. 
list. But this is not the case. The two groups are by no means t'ung yung aud are far apart in the rime list. Here Maspero's system breaks dowu.

Another example. For the rimes 欣 (殷), 文 Maspero constructs a -an (-ion, nion) and they thus ought to be extremely t’ung yung with 魂, 痕 $(-u a ̆ n,-a ̈ n)$. This however, is not so, and in order to explain that fact Maspero has to suppose that 欣, 文

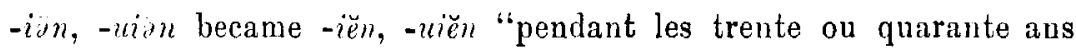
qui séparent Lou lia-yen [the author of 'Ts'ie yün] et Hü King-tsung" (p. 65; cf. p. 51 where it is said that Hü was "le contemporain un peu plus jeune de Lou Fa-yen), - an obviously impossible supposition. But even this desperate endeavour to get out of the difficulty is of no avail; for if Hü pronounced 欣, 文 $-\breve{e n}$, he ought to have made these rimes t'ung yong - not with 魂, 痕 but - with 傎, 謗 (Maspero: $-\breve{e n}$ ), which is not the case either. This new difficulty does not escape the sharp anthor, and he has to meud his theory by supposing that not all -ian had become -ién, but some of them (those with labial initial and ho kou) -ion instead, and this would be the reason why the rime as a whole could not be marked as tung yung with 面 etc. -ěn. This argumentation throughout is too artiticial and full of unlikely suppositions to be really considered, it mainly serves to show how inspossible it is to make Maspero's t'ung yung theory agree with the given facts.

4) With Maspero's theory there are further several phenomeua which cannot be explained.

Maspero accepts my theory that certain words which in Foochow have -ie (in rime 支) have bad an old $i e<-i \alpha$. But, he says, that was loug before the time of the Ts'ie yün; in Ts'ie yün all the rimes 支, 脂, 之 were $-i$ because they were t'ung yung. How then will Maspero explain that very nearly all the words with 
archaic -ia jnst appear in the rime 支 and not in the rimes 脂 and 之? If they all were $-i$ in the language of Lu Fa-yen, had this author any knowledge of Archaic Chinese which enabled him to unake a special rime for $-i<-i n$ ? Of course not. Even if the three rimes were t'ung yung in the work of Hü King-tsung (which is not certain), they were different in the lauguage of Lu: $\frac{-1}{\boldsymbol{x}}-i e$, 脂, 之-i (the latter two having probably some quantitative difference which I cannot trace).

If one would suppose, in order to meet this objection, that Lu Fa-yen employed older fan-ts'ie, then this of course bears not only upon this special word group but upon his whole system, and that would purport that the whole language embedled in the $T s^{\text {'ie }}$ yü (with its rime distinctions etc.) is really older than the 6th c. an idea that might not be entirely impossible but which seems little probable.

Another case. I have shown above that Sino-Korean renders rime 元 just as well as $\mathrm{r}$. 仙 and 先 by $-2 n$ (ho k'ou -uan) but rime 魂 with - on and 朖 with -in (rarely - $\breve{c} n$ ). Now, if 元 and 魂, 痕 (all t'ung yung) really were identicai in rowel quality, as Maspero thinks, how is the attitude of Kor. to be explained? Sino-Korean must, as we have seen (p. 4) have been practically contemporaneous with Ts'ie yün, and its treatment of rime 元 does not agree with the $\mathrm{Wu}$ dialect (Go-ou) but with Kan-on which is based upon North Chinese, like Ts'ie yün. It is evident that $\vec{\sim}$, though Hü may have made it t’ung yung with 魂, 痕 had not a head vowel of the same quality as the latter rimes.

5) Obviously Maspero would gain a strong support for his theory if he were able to show that the same spelling characters were used indiscriminately in the tiung yung rimes; in other words that the rimes of Ts'ie yiun were not kept strictly apart in the fan-tseie. One would therefore expect a long and convincing list of 
examples of such confusions of rimes through the use of the same final spelling character in two tiung yung rimes. What Maspero gives (p. 54) is 8 examples.

In examining these examples it is important to go, not to the Kuang yiun (11th c.) but to the Ts'ie yuin itself. As luck would have it, Sir Aurel Stein has found in Tun Huang inter alia a Ts'ie yün manuscript (British Museum Ms. Stein 2071) in which the first ping sheng rimes, the last ju sheng rimes and the whole of $k^{\prime}$ 'ï sheng are nissing, but which none the less gives us the major part of Ts'je yün in a good, readable hand. Dr. Lionel Giles from the outward appearance dates the mannscript at the beginning of the 9th c.; and it is certainly an authentic and good copy of the 'Ts'ie yün ${ }^{1}$ ).

The examination of the Ts'ie yün manuscript gives several interesting results.

) The rime list is not, as one would have thought, exactly the same in Ts’ie yün as in Kuang yün. 'In p'ing sheug for instance 'T'sie yün has 3 rimes less: to Kuang yün 页 and 諒 corresponds only 真, to Kuang yün 寒 and 桓 only 寒, and to Kuang yüu 歌 and $\mathbb{X}$ ouly 歌. The reason of this is easily detected. The difference between the Kuang yün rimes in question is, as I have shown in my I'honologie, only the vocalic medial $u$ (ho k'ou): 寒 - $a n$ 桓 -uan etc., and the whole is a matter of taste.

1) In the Stein collection there is also another manuscript (Stein 2055) containing the preface of $\mathrm{Lu}_{\mathrm{A}} \mathrm{F}_{\mathrm{A}-\mathrm{Ykx}}$, the list of the shang ping rimes and the first of these rimes. It is a question whether we have not here a fragment not of the Ts'ie yün but rather of the T`ang yün, for Stein 2055 presents a somewhat augmented form of Stein 2071. Thus we find e.g. in Stein 2071 in rime 之, under 椟: 理之反 七 (the said char. and six morc), and in Stein 2055: 梩: 理之反七加二(the seven above with the aduition of two). It is true that 2055 just as 2071 does not always agree with the "T"ang yün" spellings we know from the Trang yün $k$ 'ao. But Maspero has given (p. 52) a vivid account of the vicissitudes gone through by this " $T$ "ang yiin" version, and the ts'ie of T'ang yün $k^{\prime} a$ must be taken with the greatest caution. 
Ts'ie yün does not consider it worth while to mark the difference by different rimes, while Kuang yüu prefers to do so. But for our t'ung yung question the matter is of importance; for Maspero writes (p. 54) in order to show the rime confusion: "隭 qui est à la rime 寒 a pour fan-ts'ie 乃官, alors que 官 est à la rime 桓”. We see that from the point of view of Ts'ie yüu, which has no rime 桓 but only 寒 there is no rime confusion.

B) Much more important, however, is another point. Maspero considers it an axiom that the fan-ts'ie of Kuang yün are identical with those of Ts'ie yün - I believed so myself earlier. Now, when the $T^{*}$ ang $y u ̈ u$ (as reproduced in the T'ang yün $k^{*} a o$ ) sometimes presents different fan-ts'ie, Maspero belieres these to be corrections. But such is by no means always the case. A scrutiny of Ms. Stein 2071 and 2055 (the fan-ts'ie of which are absolutely identical) gives the result, that while the spellings in 9 cases out of 10 are the same as in Kuang yiin, yet there are some divergences. As a rule they do not influence the phonologic position of the word. Thus 奜 both in 2071 and in 2055 is spelled 罒: 肥, while Kuang gün has 甫: 微. Both fant-ts'ie place the word in rime 微 with yodicised initial. But for the t'ung yung problem these variations are of importance. Maspero says for instance (p. 54): “鵬, 屍, 茬 qui sont à la rime 脂 ont pour fan-ts"ie 式之 alors que 之 est lui-même une autre rime et que d'ailleurs 之 et 脂 sont t'ung yung". But Stein 2071 has not as final ts'ie for 沜, 屍, 菬 the char. 之 but the char. 脂, and it is Kuang yüu (11th c.) and not Ts'ie yün which has the honour of the confusion in question. Maspero further cites the rime char. 夬 spelled 賣 in Kuang yün while 賣 belongs to rime 快. Unfortunately $k^{*} u ̈$ sheug is missing in the Stein manuscripts, but as the version of 676 A.D. according to Maspero had not 賣 but 䔽 (which latter is correct) and as we have seen that Ts'ie yün and Kuang yün 
do not always agree in their spelling, we have just as good right to suppose the correct 遇 as the erroneous 賣 for the Ts'ie yün.

7) Finally and above all it nust be remembered, that when you try to show a rime confusion in $7 s^{*} i e$ yün, you must not labour with Kuang yün forms of unusual words. It is a well known fact that Trang yüu was an enlarged version of Tsie yün and again that Kuang yün was an enlarged version of T'ang yün. Out of the few examples cited by Maspero as proofs of rime confusion in Ts'ie yün several can be eliminated because they do not exist in the Ts'ie yiun (Stein 2071)! That the Kuang yün of the 11th c. has been guilty of some bluuders cannot reasonably be a matter of reproach to Ts'ie yün which is half a millenninm older.

$\delta)$ Even the rime confusions sigualized by myself in my Phonologie are removed by the Ms. 2071. The rime 凡 is confused in Kuang yün with rime 咸 because the char. 凡 is spelled by 咸. But Stein 2071 has as spelling char. not 咸 but 芝, which is quite correct $^{1}$ ). 咸 is spelled in T'ang yün (cited in K'ang-hi) by 監 (confusion of rimes 咸 and 洤) but Ts'ie yün (Stein 2071) and indeed even the Kuang yün give as fan-ts'ie 胡: 讂 which is correct ${ }^{2}$ ).

In fact, if we fix upon the characters that are not too uncommon, such as existed already in the Tseie yün, it is remarkable indeed how extraordinarily well the rime distinctious arc reflected in the fan-tsie distinctious. Each rime has its own set of spelling characters, which practically never occur in other rimes. The best examples of this fact are just the tables of more than 3,000 common characters given in my Phonologie, in which the absolute correspondence

1) Maspero's elaborate passage p. 117 thus becomes superfluous; I had already carlier (Phon. p. 3I) supposed that 咸 for 凡 was a blunder, and this turns out to be true.

2) For 帆 K'ang-hi erroneously cites 焱 - Kuang yün spells it 凡. 
between the fan-ts'ie system and the rime system is fully shown. It is so far from being as Maspero says (p. 55): "les rimes t"ung yung étaient identiques les unes aux autres", that on the contrary the t'ung yung rimes, just as well as all other rimes, can be said to have been rigorously distinguished by the fan-ts'ie.

6) What, then, was the meaning of the terms t'ung yung and tu youg - if we for the sake of argument accept the theory that the t’ung yung arrangement of Kuang yün goes back to Hü King-tsung.

It would be very easy to suppose that Lu Fa-yen had taken over - as it often happens in China - both rime system and all the fan-ts'ie from a somewhat older epoch; that the language of Ts'ie yün was not that of the 6th but say of the 5th century, and that certain rimes distinguished in that epoch had time to coincide in the language of Hü King-tsung. But not even this seems very likely to me, for I do not believe that rime $\overrightarrow{\text { 元, }}$ t'ung yung with 魂, 痕, was ever confused with (or had the same head vowel as) these rimes in any phase of the language, that of Hü or any other: they have never been treated alike, from SinoKorean down to modern times.

We do not know what the work of Hü King-tsung was like, but it is very natural to suppose that Hü was the first to labour with that linguistic grouping of the material which bore such excellent fruits in the Sung period (rime tables of Si-ma Kuang etc.). His first experiments must necessarily have been rather primitive, and he was content to group together here and there rimes which without being identical - yet were rather similar to each other. Thus in his work certaiu rimes came to be 同用 "used together" while others were 猛用 "used alone". This seems to me to be the simple explanation of these terms, to which Maspero - in my opiuion incorrectly - has attached such enormous importance. 
C. The medial $i$ and some discussable rimes.

1) An important improvement upon my reconstructiou system has been made by Maspero concerning the so called "independent IId division" of the rime tables, words like 州, 巴, 咸, etc.

I reconstructed in this category of words a rudimentary medial $i$ : $k^{i} a, p^{\prime} u$, riam on the strength of the Mandarin forms kia, hien etc., but Maspero proposes, and I believe he is right, that these forms are due to a palatalising phenomenon which appeared during the T'ang epoch. The $-a(-)$ in these words being very high ("aigu"), as I have proved myself in the Phonologie, it had the power of palatalising the preceding gutturals: $k a>k i a\left(t^{\prime}\right.$ sia $)$ in certain Northern dialects. I have myself earlier reflected upon this possibility, but it did not appeal to me because the medial $i$ in Mandarin exists also in the group 江 which $I$ have proved to have had a final ing in Tsie yür. That an open o (ii) should have caused palatalisation seemed impossible to me. Now, however, Maspero has given an excellent account of the fate of the said -ang during the T'ang period, and it forms no longer any obstacle to the palatalisation theory. One difficulty remains: the words with laryugal initial, 莖 etc., Auc. Chin. 'a, have also developped an $i$ : Pek. ia etc., and it seems somewhat farfetched to suppose an evolution ' $a>i$ ia because of the "timbre aigu" of the rowel; but this apprehension has to give way for the very serious advantages in other respects of Maspero's theory.

2) One of the most important results of $\mathrm{my}$ earlier researches - important because it throws light upon the whole structure of Ancient Chinese - which has been entirely neglected by Maspero because he disregards the Sino-Korean, is the distiuction between consonantic and vocalic medial $i$. In my Phouologie (p. 627) I have shown that Sino-Korean had a remarkable distinction which answers exactly to a rime distinction in Tsie yün (仙 against 先 etc.). 
Even if Sino-Korean were based upon the $\mathrm{Wu}$ dialect, we thus would be bound to pay regard to this phenomenon, as it would simply show a parallel evolution in this respect of the old North Chinese and the $\mathrm{Wu}$ dialect. But as $\mathrm{I}$ have proved above (p. 7) that Sino-Korean in regard to these rimes (as in most other respects) agrees with Kan-on (built upon North Chinese) and not with $\mathrm{Wu}$, we have all the more reason to give our best attention to this phenomenon, which is of decisive importance:

\section{Rime 仙}

(and corresp. r. in other tones)

Anc. Chin. Kor.

衍 krjiän kon

虔 $g^{*} j i a i n \quad k a n$

件 g'jiän kan

諺 $n g j i a ̈ n$ an

脊 $k j i^{\prime \prime}$ "an $\quad k u a n$

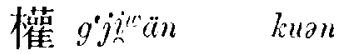

Rime 先

(and corresp. rimes)

And the same distinction is found in the words in $-m$ :

Rime 監

(and corresp. rimes)

儉 gijiüm $\mathrm{kam}$

險 $x j i a ̈ m \quad h a m$
Anc. Chin. Kor.

堅 kien kian

毫kien kian

賢 zien hian

研 ngien ion

玄 $z^{i "}$ en lion

奬 $x^{i \prime \prime}$ en hizn

The evidence of all other dialects shows clearly that both rime 仙 and rime 先 had medial $i$. But as Sino-Korean does not reproduce the medial $i$ in $r$. 仙 (after certain initials) but always reproduces it in $r$. 先, I have drawn the legitimate conclusion, that the medial $i$ was stronger in $r$. 先 than in $r$. 仙; in other worus that $r$. 仙 had a consonantic medial $\underset{\sim}{i}$, while $r$. 先 had a vocalic medial $i$. In my Phouologie I wrote -rin in them both, it is true, but I supposed (p. 628) that the rowel was more open 
after the weaker, consonantic $i$, and following up this idea I now adopt the writing 仙 -iän: 先 -ien. It is undoubtedly this vocalic difference which has determined the rime distinction ${ }^{1}$ ).

The difference between consonantic and rocalic medial $i$ is of extreme importance, for it explains the strict distinction in Anc. Chin. between yodicised and not yodicised initials. The consonantic medial $i$ yodicised the initial but not the rocalic one: ${ }^{2}$ )

\section{甄 kjizin: 堅 kien.}

So far all is very well and I have every reason to cling to my system in the Phonologie. But then there arise grave difficulties, to the solation of which Maspero has indirectly shown me the way.

3) I showed in the Phonologie that in the IIId and IVth divisions of the rime tables there were rimes of three different types, each of them occurring with a fixed set of initials. If we symbolise all gutturals and laryngals with $k$, all palatals and supradentals with $t$ 's, all dentals and laterals with $t s$ and all labials with $p$, and limit our survey to the tables 山, 成, 庆, 蟹, 鉌, we get the following synopsis:

Rines of type $z)$ :

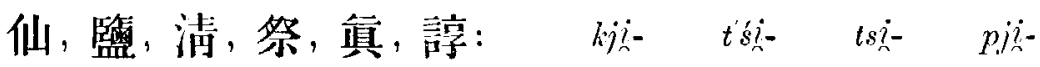

$k j i_{n}^{\prime \prime}-\quad t^{\prime} \hat{i}^{\prime \prime}-\quad t s t_{n}^{\prime \prime}-$

Rimes of type $\beta$ ):

1) Maspero gives an interesting hint that he is ready to show in a future work, that the words of rime 仙 (-iïn according to me) had an older -ian, while those of rime 先 (-ien acc. to me) come from a monovocalic en. If this be so - it is not proved as yet it would be highly interesting; it would show, that while the old medial $i$ was consonantic $i$, the comparatively new medial $i$, arisen through the "breaking" of an $t e$-into a diphtong was of another type: vocalic -ie-. If there has really been such a breaking, it has taken place long before the Ts ie yün, as both types existed in the language forming the basis of Sino-Korean, which was practically contemporaneous with Ts ie yün.

2) Yodisation was also the rule when the head vowel was an $i$ : 基 kiji, 夸 kijie, 機 kjei. 
元, 嚴, 凡, 庚, 廢, 欣, 文: $k j i-$

$$
\text { k.jilim- }
$$

0

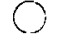

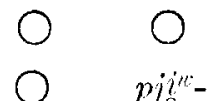

$p j j_{n}^{i r}-$

Rimes of type $\%$ :

先, 添, 青, 离:

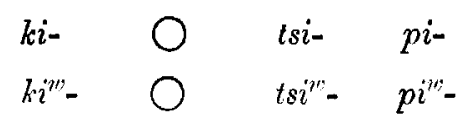

For the moment we leave rimes 真, 暲, 欣, 文 out of the discussion. In regard to the rest, we have just witnessed what it was that constituted the difference between type $z$ ) and type $\gamma$ ):

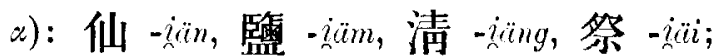

y): 先 $-i e n$, 添 $-i e m$, 青 $-i e n g$, 否 $\left.-i e i^{1}\right)$.

The salient point is the rimes $\beta$ ).

In my Phonologie I supposed - for more suggestive than binding reasons - that even here it was a question of a varying degree of strength of the medial palatal element. I constructed for instance $\alpha)$ kjiän $\beta$ ) kjïn $\gamma$ ) kizin. And I added that in all probability there was a corresponding gradual opening of the vowel "timbre": z) kjiain (3) $\mathrm{kj}^{\mathrm{i}} / \mathrm{a}$ (something like Engl. $a$ in man) y) kien. Maspero, though refuting this theory, calls it "séduisante". I must admit myself that I have never considered it very seductive but on the contrary rather artificial. It simply was the only way out of the difficulty of the rimes $\beta$ ) for which I could advance any reasons at all. Now Maspero has helped me to a better idea - though I caunot accept his interpretation.

I give up the idea of a third degree of strength in the medial palatal element (kjön). The parallel iu Anc. Chin. between medial $u$ (ho k'ou) and medial $i$ was absolute. Medial $u$ could be vocalic

1) Maspero has accepted an open $e$ (i.e. $a$ ) in rime 清 and a narrow $e$ (i.e.e) in rime声. But as 仙 and 先 are tiung yung, he has not been able to draw the consequence for this group. After what $I$ have alleged in the t'ung yung question it is evident that I treat the two groups in an aisolutely parallel way in this respect. By the way I may mention that Maspero, when mentioning my reconstruction system for the rimes 庚, 清, 青, has reproduced it in a very distorted way (p. 56). 
(官 Anc. kuân, Cant. kinn) or consonantic (關 Auc. $k^{*} a n$, Cant. kwan). And similarly medial $i$ could be vocalic (rimes $\gamma$, 先 etc.: 堅 kien) or consonantic (rimes $\%$, 仙 etc.: 甄 kjicin, and also rimes $\rho$, 元 ete. : 建 $k j i x)$; there was no third degree.

Then it remains for us to find another explanation of the rimes $\beta$. And the way to this is shown by the fact held forth by Maspero, that rime 元 in the rime list of Ts'ie yün is placed together with 魂, 痕 (and possibly has been marked as t'ung yung with these by Hï King-tsung). And the head vowel of 魂, 痕 was undoubtedly $\partial^{1}$ ).

This fact, it is true, cannot make me accept the construction of Maspero: 元 - $ә n$, 魂, 痕 $\partial n$. We have seen how Kan-on (7th c., only half a century later than the Ts*ie yün) renders 元 always by -en after gutturals and laryngals, and with -en or -an after labials, while it renders 痕 by -on. And exactly similar is the case of Sino-Korean, which cannot be appreciably later than Ts'ie yün and which in these rimes agrees, not with the South Chinese Go-on but with the North Chinese Kan-on. Sino-Korean has for rime $\overrightarrow{\mathrm{U}}$ after gutturals and largngals $-\partial n$ (i. e. old Kor. $-i(i n)$, after labials $-a n$ (i. e. $-i n n)$ or $-a n$, but for rime 痕 -in. In Ts'ie yün - and the older stages we do not discuss here - therefore $r$. 元 had not the same head rowel as $r$. 痕, but a vowel which was more similar to $\ddot{a}$ (仙 Auc. Chin, -icin was rendered in the same way as $\vec{\pi}$ in Kor. and Kan-on) than is the vowel -o (痕). But on the other hand the head rowel must have had some affinity with $\partial$, a "taste" of $\partial$, as follows from the just mentioned position of $r$. $\overrightarrow{\mathrm{U}}$ in the rime list of Ts'ie yün. And, finally, the rowel must have been of such a quality, that the Korean and Japanese borrowers hesitated between $e$ (ii) and a for its reudering.

1) Maspero alleges good reasons for the supposition of short head vowel in the whole of the rime table 銯. 
The result is hardly dubious: the head rowel was $v^{1}$ ), the vowel of Engl. but, an a partaking of a and $\left.a:^{2}\right)$ 建 Anc. kjinn.

This solution remores all aifficulties. For on the one land it is easy to understand that Lu Fa-yen placed $-p n$ ( $\bar{\tau}$ ) together with $-2 n$ (痕), with which it had a decided affinity (and that Hü King-tsung perhaps brought them together as t'ung yung). On the other hand -imn is so similar to -iim, that it is eastly understood why Koreans and Japanese treated a kijimn and a kjiän alike (Kor. kon, i. e. kän, Kan-on ken). And fiually there is nothing astonishing in the fact that when they had to render a $p j i i^{\prime \prime}$ m they fluctuated between - ïn and -an (Kor. pan, i. e. pän, or pan; Kan-on pen or pan $)^{3}$ ).

Thus in table 山 we get:
a) R. 仙: $k j i a n, k j i_{n}^{\prime \prime} \ddot{a n}$

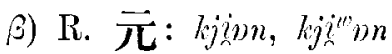
y) R. 先: kien, ki'”en

and the scheme becomes something similar to that of English:

$$
\text { 'pan' (i. e. pän): 'pun' (i. e. pun): 'pen' (i. e. pen). }
$$

This result can without risk simply be applied to the rime tables 售, 成 and 庆 which form striking parallels to the table 山.

a) The table 蟹: ${ }^{4}$ )

1) In fact Maspero thinks that the $\overrightarrow{\vec{\jmath}}$ words with labial initials during the $\mathrm{T}^{\mathrm{a}}$ ang period developped this vowel, e.g. 反 fuwn. I simply carry this construction of his higher up in the line and apply it to the whole of $r$. $\bar{\pi}$ at the time of i's ie yiin.

2) Cf. Viëtor, Elemente der Phonetik $k_{5}$ P. 99: Die Zungenhebung des kurzen $v$ ist etwas höher nnd mehr oder weniger zur "gemischten" Stellung vorgeschoben, wodurch sich ausser dem $a$-ähnlichen, jedoch etwas dumpfen Laut auch ə- oder sogar $\ddot{a-a ̈ h n l i c h e ~ V a r i e t a ̈ t e n ~}$ ergeben.

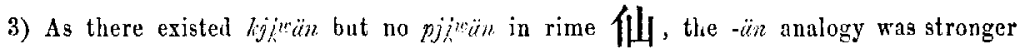

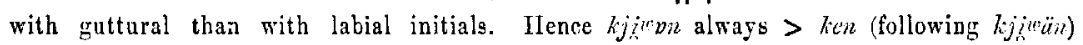
but $p j i n p_{n}>$ pen or pan.

4) Maspuro has overlooked the fact that there are several rimes in the table 蟹, this becanse he has limited his researches to the p'ing sheng words, where by chance rimes $\alpha$ ) and $\beta$ ) are missing. 
a) R. 祭; kjiä $k j i^{\prime \prime} \ddot{a} i$

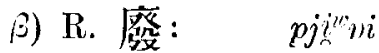

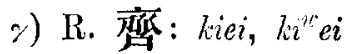

b) The table 咸:

\&) R. 鹽: kjiäm

ค) R. 嚴: $k j i n m$, 凡: $p j i^{\prime \prime \prime} m m^{1}$ )

y) R. 添: kiem

It is astonishing that Maspero for 嚴, 凡 reconstructs -iam, without seing the striking resemblance to the case $\bar{\tau}$. Kan-on has -en after gutturals, -en or -an after labials; Sino-Korean has $-a m$ (i. e. - $\ddot{a m}$ ) after gutturals, -am or - $a m$ after labials; the parallel with $\bar{兀}$ is perfect. Moreover Maspero believes 元 to have come from an Archaic Chin. -ion (a theory which, though still unproved, seems quite likely) and he tries to show a similar origin for 凡: Archaic -iom (this seems quite good, as 凡 is phonetic part in characters like 風 Anc. pjinng $[<$ pjizum through dissimilation) and 藏brung [<brum equally through dissim]). Now, if 元 and 凡 both come from Archaic -ion, -iom, I fail to see the reason why they should not be parallel in Ts'ie yün.

c) The table 庚: ${ }^{2}$ )

o) R. 清: $k j$ jiäng, $k j_{n}^{i w a ̈ n g}$

今) R. 庚: lijiong, kjitrong

v) R. 青: kieng, ki"'eng

As rimes 清 and 庚 are marked as t’ung yung in Kuang yün, Maspero has had to suppose an -äng for them both. This however is entirely impossible. For 庐 belongs to the IId division as well, where there can never have been the question of an - äng (Maspero

1) I am unable to state the difference between these two rimes; taken together they correspond to $\vec{\pi}$ in table

2) I believe Maspero is quite right in supposing short head vowels in the whole of this table. 


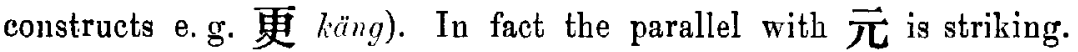
Kan-on and Sino-Korean ${ }^{1}$ ) fluctuate between $a$ and $a$. In the IId diviaion, where there was no medial $i$, one has chosen in farour of $a$ : 更 Anc. kmmg, Kor. kăing ( $i$ marks the quality of $-n g$ ), Kan-on $k a-u$; in the IIId division, after $i$, one has chosen in favour of $\ddot{i}$ : 京 Anc. kjimng, Kor. kiang (i. e. kiimg), Kan-on kei (in analogy with rime 清 -iang, reudered by Kor. -iang, Kan-on -ei). It is easily seen that Maspero's küng in the IId division never can explain the forms of Aucieut North Chinese.

By the way it is a rather interesting fact that already in $m y$ Phonologie (p. 671) I supposed - on the strength of a rich dialectal material ${ }^{2}$ ) - an $-m n g$ for rime 庈 in the IId division: 更 " $k$ ' $m g$ " etc. In order to maintain my theory about the rimes $\approx$ (jï̈ng): $\beta$ ("jüng"): $\gamma$ ("iün") I was forced to accept a divergence: $-n n g$ for the 庚 of the IId div. and -iing for the 庚 of the IIId div., which was decidedly bad. In fact I nearly stumbled upon the correct solution of the problem of the rimes $\beta$. If I had extended my vowel $n$, obtained by dialect study in the IId div. of $r$. 庚, to the IIId div. of the same rime, and then further to the corresponding rimes in other rime tables (元, 宸, 凡, 廢), I should have found that which has now come to me thanks to Maspero's important observation of the affinity between 元 and 痕!

So far the rime tables where there exist rimes of all the three kinds ( $\alpha i i i-, \beta i n-, \gamma i e-$ ). But we have further to discuss the rimes 真 (with the ho k'ou 棓) and 欣 (with the ho kou 文).

真 is a rime of the type $\alpha$ and 欣 a rime of the type $\beta$. I consequently had recoustrueted $\alpha$ ) 傎 $k j i a n$ (棓 kjinuan), $\beta$ 欣 kjan

1) Here as in ncarly all other respects Kor. has no connection with Wu (Go-on): 更 Kor. käing, Go-on ki-ya-u, but agrees with Kan-on (North Chinese).

2) That Maspero throughout his treatise entircly disregards the modern dialects is a weakness. 
(文 kjuan). As I have now abandoned the idea of a third strength degree of the palatal element ("kjan"), another solution must be found for these rimes, and Maspero has found it. While Maspero

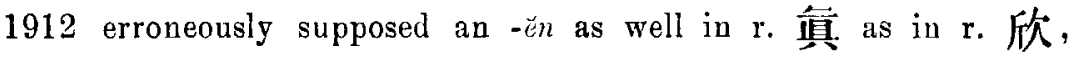
and while I equally erroneously in my Phonologie supposed an -an in them both, the truth is that 奥 was an ancient -in (少 詝 kjiün) and 欣 an ancient - on (欣 kjian, 文 kjiuan). Maspero (pp. 67, 68) gives arguments for this which seem to me to be quite conclusive. Besides the proofs he gives, one could allege that with the said reconstruction the attitude of Kan-on in the ho kou words becomes more intelligible:

$\begin{array}{ll}\text { Ts'ie yün } & \text { Kan-on } \\ \text { 均 kjinum } & \text { kin } \\ \text { 䓃 kjizuon } & \text { kun }\end{array}$

The $\epsilon$ (perhaps an $e$ rather "aigu") was acoustically rather affinited with the $i$, and thus, put between two very palatal vowels, the $u$ could more easily be skipped by the foreign borrower than in kijiuon, where it is followed by the "neutral" vowel $a$.

\section{The rime tables 遇 and 通.}

In regard to these two tables Maspero has advanced several theories which I must refute.

1) For the Ist division of group 遇 - words like 姑, 都 I had reconstructed an - $u$. Maspero has accepted this, but ouly for a somewhat later stage: he supposes an $-u$ in Tseie yün, which became an -uo during the Teang period. This, lowever, is impossible.

a) Firstly one might point out that words of this type have $-u$ in all modern dialects. On the other band Kan-on and SinoAnnamese show clearly that there existed an -o during the T'ang. It must then be said to be highly unuatural (though of course not 
exactly impossible) to suppose an evolution in circle in all these words: Ts'ie yün $k u>\mathrm{T}^{*}$ ang $k u o>$ modern $k u$.

b) More important is the testimony of Sino Korcan, which iu this respect as in most others agrees not with Go-on (Wu) but with Kan-on:

$\begin{array}{ccc}\text { Kor. } & \text { Kau-on } & \text { Go-on } \\ \text { 姑 } k o & k o & k u\end{array}$

This shows that the final -o existed already at the time of Ts'ie yün.

c) Moreover, even for Archaic Chinese we have necessarily to suppose a final $-o$, not an $-u$. This follows from the very numerous cases where words in this -o serve as phonetic parts in the characters for words in - $a$ and vice versa; a few examples will suffice here one could easily give dozens.

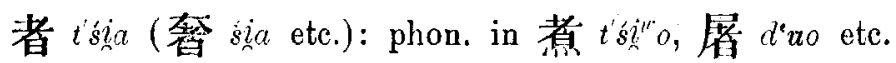
且 $t s^{i} i a$ (姐 $t s i a$ etc.): " " 助 $d \xi^{i} t^{t \prime} o$, 租 $t s u o$, 粗 $t s^{*} u o$ etc. An Archaic $-u$ could never explain the great number of such cases. Thus the evolution was, at least in certain of these words: Arch. and Anc. kuto > Middle and Modern Chin. ku.

2) In the case of rime 東 on the contrary we know for certain that Ts'ie yün had -ıng, e.g. 公 kung etc., because 弓 kjiung belonged to the same rime. But on the other hand Sino-Korean and Kan-on show (Kor. 公 kong, Kan-on ko-u) that already at the beginuing of $\mathrm{T}^{\mathrm{e}}$ ang some Northern dialect had a final -ong. This dialect variation I marked thus in my Phonologie: ku(o)ng.

Whether this Northern kuong, corresponding to Ts'ie yün kung, has arisen from kung or not, is not the place to discuss here. It may very well have done so, without hinder for supposing the circle kung $>$ kuong $>$ kung. For the case is not quite parallel with the case kuo just discussed. At the side of $r$. 東 there existed r. 冬 -uong, which may have exerted an analogic influence upon 東, creating a 公 kuong, 東 tuong in certnin localities. 
3) In regard to rime 冬 Maspero is inconsistent. On p. 77, where he discusses the rime in detail, he writes tong etc., without medial $u$, but later he seems to have changed his opinion and conse round to my reconstruction of it, for in bis "tableau d'ensemble" at the end of the volume he writes -uong for this rime.

4) We finally have the question of the rime 鍾 in the IIId and IVth divisions, where I have reconstructed an - $i^{\prime r}$ ong: 萑

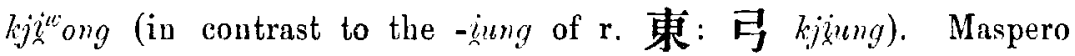
accepts this, but only with a reservation. He tries to show that the ho k'ou " existed only after the gutturals, but not after the palatals: kjijong but tsiong. This would not appear in the fan-tsie, but it would be revealed by Sino-.Japanese. 'The whole of this theory is very strange.

In the first place it would be curious if the fan-ts'ie, generally so strict in regard to $\mathrm{k}^{*} \mathrm{ai}$ or ho $\mathrm{k}^{*} \mathrm{ou}$, would be inconsistent on this poiut. But above all, the ouly proof Maspero has to give is entirely deroid of value. It is a well known fact that Sino-Japanese often renders medial $u$ after gutturals but always skips it after dentals (and palatals: Jap. always renders palatals by dentals), and this even when it is a rocalic $u$ !

Ts'ie yün 官 kuân, 灰 zuâi, 果 kuâ: Jap. ku-wan, ku-wai, ku-zva; but:

Ts'ie yün 端 $t u a ̂ n$, 堆 $t u \hat{a} \hat{i}$, 坐 $d z^{\circ} u \hat{\imath}$ : Jap. tan, tai, sa.

It is therefore quite regular that $w$ should be skipped in t's $y^{\prime \prime}$ ong. If Maspero conclusion concerning the rime 鍾 were accepted, then we could equally well from the examples just given conclude that words like 端, 堆, 坐 had no medial $a$ in Ancient Chinese!

The lack of medial $u$ in Sino-Japanese never proves anything at all, but its existence in a rime like this after the guttural initials in Sino-Japanese is so much the more important. For if it can thus be traced to have existed after some initials, we can conclude 
with absolute safety that it existed after all, as we know the strong consistency of the fan-ts'ie on this respect.

My reconstruction - $i$ : ong for the whole of rime 鍾 is therefore correct.

E. The rimes 唐 and 陽.

These two rimes are ting yung and Maspero therefore wants to prove an $\hat{a}$ "grave" not only for 唐 but also for 陽. In order to do so he cites the transcriptions in a Tibetan manuscript, which canuot with certainty be said to be older than the 11 th century. But Ts'ie yün was written in the 6th c., and I think it would be risky to cite the "timbre" of a French vowel of the 20th c. as proof for its "timbre" in the 15th. Moreover the Tibetan document was evidently based on a Western dialect. Now it is well known that certain dialects, in opposition to the general North Chinese, have had an evolution -iang $>-$ Long in analogy with -âng >-ong; and this not only in Southern China (Foochow, Hakka 香 hiong) but also in Western Mandarin, e.g. Lanchou 香 sid, (open o nasalised, see Pbonol. Chin. p. 319). The transcriptions in question thus relate to a dialectical phenomenon in Western China, and Maspero's proof has no value. I have every reason to keep to wy reconstruction 唐 - $\hat{a} n g$, 陽 -iang, which explains the rime distinction.

F. The rime 微.

For this rime I had reconstructed an -ei (bo k'ou - ${ }^{w} e i$ ) e.g. 機 kjei, for reasons set forth Phonol. Chin. p. 646; but Maspero rejects them and proposes in stead an -ig. And what are his arguments? As far as I can see the only reason advanced is that the said rime occurs only after gatturals, laryngals and labials, just as rimes 欣 (文) (-ion with short a) and rime 元 (for which Maspero - erroneously see p. 28 above - has accepted an -ian with long 2 ). 
This is a typical example of the risk of drawing conclusions from insufficient premises. For the limitation to these initials obtained not only in the said rimes but also in the rimes 嚴, 凡, for which Maspero constructs -iam (cf. p. 30 above), in rime 廢 which Maspero has forgotten, as he treats only ping sheng rimes, and above all in rime 庚, IIId division, for which Maspero has (incorrectly see p. 30 above) given an -iüng (see Phonol. Chin. p. 180 ff.). His construction therefore is quite gratuitous. If the reasons for my reconstruction, given in my Phonologie, which I hold to be quite good, are not considered sufficient, $I$ am ready to give some more.

That the rime 微, historically considered, is of the type -ai and not of the type -ia (with $a$ I mean a rowel the quality of which I do not discuss for the moment) follows clearly from the composition of the Chinese characters, in which the phonetic parts are of great help for linguistic research:

非 $p j^{\prime \prime} e i$ is phonetic in 裴, 徘 $b^{r} u a ̂ i$, 棑 $b^{\circ} a i$, 排, 俳, 輫 $b^{2} a i$.

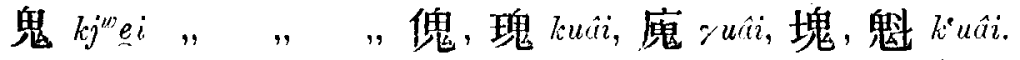

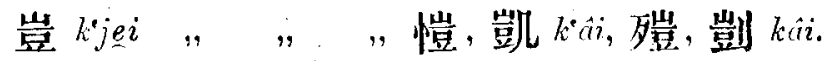

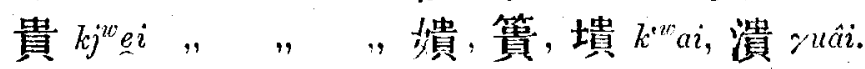

蒙 ngjei $i \quad "$, 隊, 㥒, 蠓 ngai.

希

氣 $k^{\prime} j e i, ", "$, 愾 $k^{\circ} \bar{a} i$.

在 ${ }^{j e i}, ", "$, 庞

韋 $z^{\prime \prime} e^{i},, \quad, \quad$, , 衛 $j i^{w} \ddot{a i}$.

㿟 kjei " " "航 k'ai.

末 $m i j^{w} e i, ", "$, 妹, 昧 muái.

The examples could easily be multiplied. It is readily seen that the ig of Maspero entirely fails to explain these phenomena:

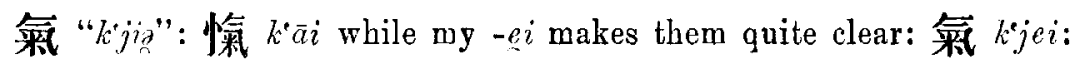
檫 $k \bar{a} i$. 
G. Two initial questions.

1) The initial $日$ was 1912 interpreted by Maspero as an Peiliot correctly stated that it must have contaiued as well a $\check{z}$ as an $\dot{n}$ (palatal nasal), and he wrote $z$. On various grounds I determined its value as $x z$ in my Phonologie. This reconstruction has been accepted by Maspero, but with the modification that he supposes an $\dot{n}(\tilde{i})$ for Tsie yün aud a development $\dot{n}>n \dot{z}$ during the T'ang period. This I cannot accept.

In 'Ts'ie yün there was another initial $n$ (尼), and this just as well as $k$ etc. occurred in certain positions yodicised: $n j^{1}$ ). Now a palatal $n$ and an $n j$ are acoustically nearly impossible to distinguish and very cognate in articulation (see e. g. various works of Rousselot), and it would be incomprehensible, firstly that the Chinese pbilologists, especially the authors of the fan-ts'ie, could distinguish them so strictly, secondly and above all that two phonems like $i$ and $n j$, if they had been coexisting, could get such extremely diverging evolution in the later language. If $n^{\prime} z$ (日) came from an older $u$, which I think is quite likely, the said $n$ must have become $n \dot{z}$ long before the language yodicised certain initials before consonantic medial $\underline{i}$, and $i$ as head vowel (kiän>kjiän, ki>kji, nizän>njiän, ni>nji), in other words; long before there arose any $m j$. This was a considerable time before the Ts'ie yün, and $\mathrm{H}$ was therefore $n \dot{z}$ already in the North Chinese of the 6th century.

2) The sonant occlusives were supposed by Maspero 1912 and by Pelliot 1911-14 to have been ordinary unaspirated $b, d, g$ etc. I have shown in my Phonologie that the dialects necessitate the supposition of aspirated sounds: $b^{*}, d^{*}, g^{*}$ etc. Maspero takes up this idea and gives some new and very interesting transcription

1) Then called 艮 by the Chinese philologists; but 民 $n$ und 艮 $n j$ together corresponded to one guttural, e.g. 見 $k$ and $k j$. 
proofs of the correctness of the theory. But he modifies it so as to suppose unaspirated $b, d, g$ for Ts'ie yün and a development $b>b, d>d^{e}$ ete. in the T'ang period. Here again I cannot follow him. His reasous, interesting enough in themselves, are a series of buddhistic transcriptions of a certain school, which sure enough are based on unaspirated forns; but this only shows, that in certain dialects the aspiration was lost very early, and this we kuew before. Sino-Annamese was probably based on a dialect with uuaspirated mediae, $b, d, g$ etc. and very likely also the Go-ou.

My principal reason for believing that the $b^{*}, d^{*}, g^{*}$, were not only as ancient as Ts'ie yün but even archaic J cannot develop here but must reserve it for a future work. But I wish to point out that if - as Maspero believes - it is the aspiration that explains the surd initials of Kan-on:

$$
\begin{aligned}
& \text { T'aug Kan-on } \\
& \text { 其 } g^{*} j i \quad k i \\
& \text { 定 dieng tei etc. }
\end{aligned}
$$

the foreigners feeling the $b, d^{*}, g^{*}$ as $p, t, k$ because of the aspiration, then the same thing must be true also of Sino-Korean (which here again does not follow Go-ou but Kan-on): 其 kai, 定tiang, and Sino-Korean cannot be appreciably younger than Ts'ie yüu.

The sonant occlusires of Ts'ie yün therefore were aspirated: $b^{\prime}, d^{\prime}, g^{\prime}$ etc.

\section{Conclusion.}

My reconstructive system of 1919 (Phonologie Chinoise, III) thus holds good with the exception of three important points, where Maspero has introduced or at least showu the way to valuable emendations:

1) The abolition of ${ }^{i}$ in the IId division: 家 $k a$ instead of $k^{i} a$.

2) -ien instead of -2an in r. 真 (棓). 


\section{3) -ip-in rimes 元, 嚴, 凡, 廢, 庐. ${ }^{1}$ )}

The fiuals of Ts'ie yän consequently were the following (systematically arranged accorling to the rime table principles of the Suivg philologists); the ping sheng rimes stand also for shang, $b$ ü and ju sheng - the ju sheng rimes differ from those of p'ing sheng by a $-p$ taking the place of $-m,-t$ of $-n$ and $-k$ of $-n g$.

Kuang yün

K'ai k'ou

Ho k*ou

rimes without $i$ with $i$ without $i$ with $i$

歌 哥 $k \hat{\imath}$

戈

麻 家 $k a$

耶 ia

果 $k u \hat{a}$

咍 誈 kâi

灰

瑰 knuâi

泰 正 $\overline{k a} i$

會 $k u \bar{a} i$

皆 皆 kai

船 $k^{\prime \prime} a i$

佳 佳 $k \bar{a} i$

掛 $k^{2 n} a i$

祭

例 lijui

徫落 $i^{k} \ddot{a} i$

廢

雞 kiei

廃 $p j i{ }^{\prime \prime} m i$

㔖

圭 $k i i^{\prime \prime} e i$

覃 感 kâm

談 甘 kim (â?)

咸 減 kam

銜監 $\operatorname{kam}($ a?)

監

銝 gijiam

嚴

檢 $k j$ jinm

1) Ir the aricicle in Trouny Pao, 1920 cited p. 1 above I bave given a list of the most common transcription characters in their old rcading. This list now ought to be emended in the following way:

a) all $i$ (rudimentary $i$ above the line) to be taken away.

b) the sequences $-j \ddot{u}-,-j w \ddot{a}-$ to be replaced by $-j i j p-,-j i^{n} p-$.

c) $-i a n,-t,-i$ inon, $-t$ to be replaced by $-i \breve{l}_{n},-t,-i u \breve{u}_{n},-t$; and $-j a n,-t,-j u a n,-t$ to be replaced by $-j i z n,-t,-j i u a n,-t$. 


\begin{tabular}{|c|c|c|c|c|}
\hline Kuang yü & $K^{\prime}$ ai & ou & Ho k'ou & $\mathbf{u}$ \\
\hline rimes & without $i$ & with $i$ & without $i$ & with $i$ \\
\hline 凡 & & & & 凡 $l^{*} j_{n}^{t^{t}} p m$ \\
\hline 添 & & 兼 kiem & & \\
\hline 寒 & 干 $k \hat{a} n$ & $\because$ & & \\
\hline 桓 & & & 官 luân & $n$ \\
\hline 山 & 熯 kian & & 鱯 $k^{w} a n$ & \\
\hline 删 & 菇 $\operatorname{kan}(\hat{a}$ ? $)$ & & 關 $k^{2 \prime \prime} a n(\bar{a} ?)$ & \\
\hline 仙 & & 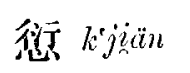 & & 權 $g^{*} j^{*} i^{w} \ddot{a} n$ \\
\hline 元 & & 建 kijinn & & 元 $n g j^{20} p n$ \\
\hline 先 & & 堅 kien & 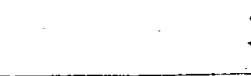 & 玄 $r i^{w} e n$ \\
\hline 唐 & 剛 kâng & & 光 $k^{w} a n g$ & \\
\hline 江 & 江 king & & & \\
\hline 陽 & & 僵 kijiang & & 筐 $k \cdot j i^{w}$ ang \\
\hline 豪 & 高 $k \hat{a} u$ & & & \\
\hline 肴 & 交 kau & & & \\
\hline 宵 & & 駚 hyiau & & \\
\hline 蕭 & & 泳 kien & & \\
\hline 深 & & 令 kjiam & & \\
\hline
\end{tabular}

痕 根 kan

魂

昆kuan

筫

ij kijzen

言高

均 kiji ün

欣

斤 kijion

文

君 kjiuan

登渡, yong

弘 $\gamma^{z t}$ ang

故 $k j i$ ing

荣

耕 耕 kpng(?)

案 $\gamma^{\prime \prime}$ ong (?) 

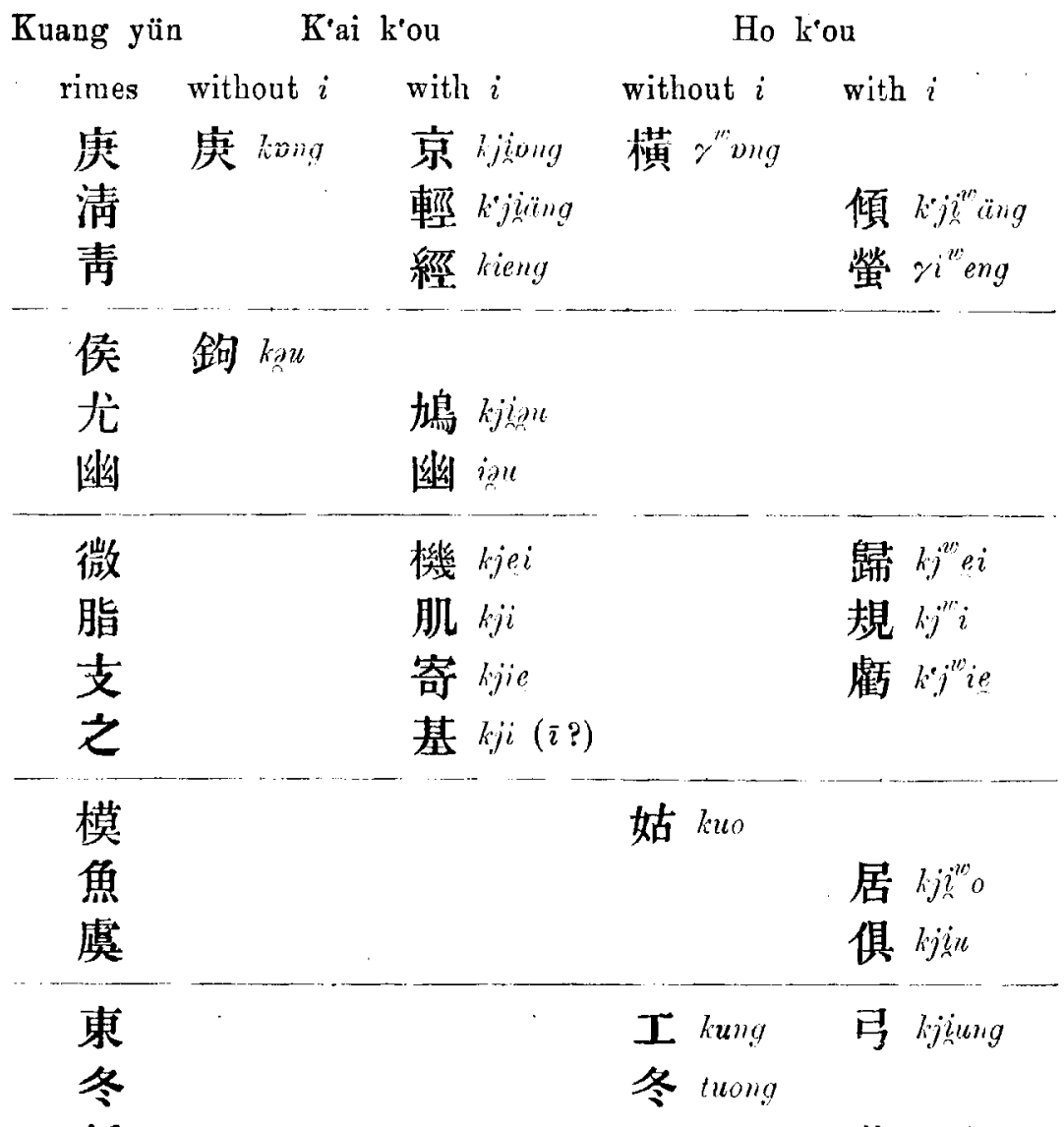

鍾

菒 $k j i^{i}$ 'ong

Just as I finish reading Maspero's suggestive aud important work, I receive a big volume: Die Hunnen der vorchristlichen Zeit, Chinesische Urkunden zur Geschichte Asiens, unterstützt von der Kgl. Preussischen Akademie der Wissenschaften, by J. J. M. de Groor, Professor of Sinology at the University of Berlin. A striking feature of this ponderous work is the astounding "old readings" of the words the author gives throughout his work. An old "Чo" gives - under exactly the same conditions - just as well a Mandarin $u$ as an ou or an $a u$; evidently professor de Groot is far above the poor old 
"Junggrammatici". The key to this remarkable fact is given in the iutroduction, p. vin: "Nicht die Silbe, sondern der Ton ist es, der den Begriff bildet, und diesem Umstand ist es wobl zuzuschreiben, dass die Silben in auffallender Weise mundartlichen Schattierungen ausgesetzt sind. So gehen mühelos ineinander über: $e$ und $o i ; i, u$,

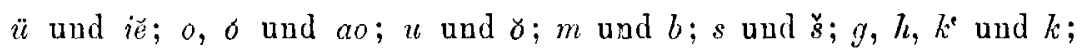
u.s.w., ohne dass es die Verstiudlichkeit der Sprache merkich beeinträchtigt. - Die Behandlung [of the language] unter dem Gesichtswinkel unserer bisher festgesetzten Lautgesetze (!!) scheint somit von vornherein zur Sterilität verurteilt zu sein; und wenn auch bis in die neuesten Zeiten hinein Sprachwissenschaftler es verstanden haben, aus den Ergebnissen solcher Arbeit sogar Bücher zu wachen, so beweist das vielleicht nur, dass sie fleissig und ahuungslos leeres Stroh droschen, in chinesischen Umgangssprachen nicht praktisch bewandert waren und dass es ihuen an Einsicht in die Natur derselben gebrach".

What a pity Maspero aud myself were not told so a little earlier, what a waste of time and labour! Vanitas vauitatum! 